\title{
KONSEP PROFESIONALISME GURU DALAM PENDIDIKAN
}

\author{
Aulia Najmi \\ Email: 2010111120008@mhs.ulm.ac.id \\ Program Studi Pendidikan Sejarah Fakultas Keguruan dan Ilmu Pendidikan \\ Universitas Lambung Mangkurat \\ Banjarmasin
}

\begin{abstract}
Abstrak
Profesi dapat diartikan sebagai suatu pekerjaan atau jabatan yang menuntut keahlian, yang didapat melalui pendidikan dan latihan tertentu, menurut persyaratan khusus memiliki tanggung jawab dan kode etik tertentu. Profesi guru adalah keahlian dan kewenangan khusus dalam bidang pendidikan, pengajaran dan pelatihan yang ditekuni untuk menjadi mata pencaharian untuk memenuhi kebutuhan hidup yang bersangkutan. Guru merupakan suatu profesi, yang berarti suatu jabatan yang memerlukan keahlian khusus sebagai guru dan tidak dapat dilakukan oleh sembarang orang diluar bidang pendidikan. guru adalah pendidik profesional dengan tugas utama mendidik, mengajar, membimbing, mengarahkan, melatih, menilai, dan mengevaluasi peserta didik pada pendidikan anak usia dini jalur pendidikan formal, pendidikan dasar, dan pendidikan menengah. Profesionalisme sangat diperlukan dalam memajukan pendidikan di Indonesia tentu juga sebagai perilaku kerja yang mengutamakan kesempurnaan hasil dengan menjalankan mekanisme kerja yang benar, hal ini sangat diperlukan untuk menunjang pendidikan Indonesia guru yang benar Profesi guru dalam undang-undang No.14 tahun 2005 tentang guru dan dosen mengharuskan sebuah komponen pokok yang harus dimiliki seorang guru profesional, kompetensi tersebut adalah; kompetensi profesional, kompetensi pedagogik, kompetensi sosial, dan kompetensi kepribadian.
\end{abstract}

\section{PENDAHULUAN}

Profesi secara etimologi berasal dari kata profession (inggris) yang berasal dari bahasa latin profesus yang berarti "mampu atau ahli dalam suatu bentuk pekerjaan". Profesi dapat diartikan sebagai suatu pekerjaan atau jabatan yang menuntut keahlian, yang didapat melalui pendidikan dan latihan tertentu, menurut persyaratan khusus memiliki tanggung jawab dan kode etik tertentu. Pekerjaan yang bersifat profesional berbeda dengan pekerjaan lainnya karena suatu profesi memerlukan kemampuan dan keahlian khusus dalam melaksanakan profesinya. (Susanto, 2020: 13).

Profesi guru berdasarkan UU RI No.14 tahun 2005 tentang Guru dan Dosen pasal 1, Guru adalah pendidik profesional dengan tugas utama mendidik, mengajar, membimbing, 
mengarahkan, melatih, menilai, dan mengevaluasi peserta didik pada pendidikan anak usia dini jalur pendidikan frmal, pendidikan dasar, dan pendidikan menengah. Dosen adalah pendidik profesional dan ilmuan dengan tugas utama mentransformasikan, mengembangkan, dan menyebarluaskan ilmu pengetahuan, teknologi, dan seni melalui pendidikan, penelitian, dan pengabdian kepada masyarakat. (Susanto 2020:16)

\section{PERAN GURU SEBAGAI SEBUAH PROFESI}

Guru merupakan suatu profesi, yang berarti suatu jabatan yang memerlukan keahlian khusus sebagai guru dan tidak dapat dilakukan oleh sembarang orang diluar bidang pendidikan. Walaupun pada kenyataannya masih terdapat guru yang tidak memiliki latar belakang pendidikan bidang keguruan (Susanto 2020:17)

Berdasarkan UU RI No.14 tahun 2005 tentang guru dan dosen pasal 1 guru adalah pendidik profesional dengan tugas utama mendidik, mengajar, membimbing, mengarahkan, melatih, menilai, dan mengevaluasi peserta didik pada pendidikan anak usia dini jalur pendidikan formal, pendidikan dasar, dan pendidikan menengah. Dosen adalah pendidik profesional dan ilmuan dengan tugas utama mentransformasikan, mengembangkan, dan menyebarluaskan ilmu pengetahuan, teknologi, dan seni melalui pendidikan, penelitian, dan pengabdian kepada masyarakat. Menurut Noor Jamaluddin (1978: 1) guru adalah pendidik, yaitu orang dewasa yang bertanggung jawab memberi bimbingan atau bantuan kepada anak didik dalam perkembangan jasmani dan rohaninnya agar mencapai kedewasaannya, mampu berdiri sendiri dapat melaksanakan tugasnnya sebagai makhluk Allah khalifah dimuka bumi, sebagai makhluk sosial dan individu yang sanggup berdiri sendiri. Sedangkan Rickey (1987) sebagaimana dikutif Soetjipto dan Kosasi (2009: 17) mengemukakan ciri-ciri guru sebagai profesi, yaitu

1) Adannya komitmen dari para guru bahwa jabatan itu mengharuskan pengikutnya Menjunjung tinggi martabat kemanusiaan lebih dari pada mencari keuntungan diri sendiri.

2) Suatu profesi mensyaratkan orangnya mengikuti persiapan profesional dalam jangka waktu tertentu.

3) Harus selalu menambah pengetahuan agar terus menerus berkembang dalam jabatannya.

4) Memiliki kode etik jabatan.

5) Memiliki kemampuan intelektual menjawab masalah-masalah yang dihadapi.

6) Selalu ingin beelajar terus-menerus mengenai bidang keahlian yang ditekuni.

7) Menjadi anggota dari suatu organisasi profesi.

8) Jabatan itu dipandang sebagai suatu karir hidup.

Seorang guru berkaitan dengan aktivitas profesinya diharuskan mengetahui dan dapat menerapkan beberapa prinsip mengajar agar ia dapat melaksanakan tugasnnya secara profesional. ( Susanto 2020: 16/17) 


\section{GURU INDONESIA DAN TANTANGAN PROFESIONALISME}

Profesionalisme diperlukan untuk memajukan pendidikan di negara Indonesia karena profesionalisme mengandung arti yang berkualitas tinggi dalam hal teknis, kemampuan guru dalam beberapa bagian, kemampuan merencanakan pengajaran, kemampuan melaksanakan prosedur mengajar kemampuan melaksanakan hubungan dengan siswa. Kemudian guru itu ahli dalam bidang yang diajarkan dan ahli dalam tugas mendidik, seorang guru itu ahli dalam bidang yang diajarkan nya, pemahaman konsep dapat dikuasaibila guru memahami psikologi mengajar. Profesionalisme sangat diperlukan dalam memajukan pendidikan di Indonesia tentu juga sebagai perilaku kerja yang mengutamakan kesempurnaan hasil dengan menjalankan mekanisme kerja yang benar, hal ini sangat diperlukan untuk menunjang pendidikan Indonesia guru yang benar, hal ini sangat diperlukan untuk menunjang pendidikan Indonesia guru yang profesional berorientasi pada kalian, dan menunjukan sikap tanggung jawab pada pekerjaan. Untuk dapat menjalakan suatu pekerjaan secara profesional atau memilki profesinalisme sidang tentu diperlukan seperangkat pengetahuan, sikap dan keterampilan tertentu. Tentu guru yang profesionalisme dapat membuat pendidikan menjadi lebih berkembang sehingga, lebih bagus untuk masa depan negara Indonesia yang mana memiliki kompetensi keahlian dibidangnya (Susanto.H:56-62)

Tuntutan keprofesionalan suatu pekerjaan pada dasarnya melukiskan sejumlah persyaratan yang harus dimiliki oleh seseorang yang akan memangku pekerjaan tersebut tanpa dimilikinya sejumlah persyaratan tersebut, maka seseorang tidak dapat dikatakan profesional. Dengan demikian ia tidak memiliki kompetensi untuk pekerjaan tersebut. Guru merupakan pekerjaan profesi, karenanya LPTK telah menerapkan kurikulum yang berdasarkan kompetensi. Kompetensi guru mencakup empat hal penting yaitu kompetensi personal, kompetensi profesional, kompetensi sosial, dan kompetensi paedagogik. Dalam hubungannya dengan tenaga profesionnal kependidikan, kompetensi menunjuk pada performance atau perbuatan yang bersifat rasional dan memenuhi spesifikasi dalam pelaksanaan tugas-tugas kependidikan mencakup karakteristik-karakteristik persyaratan yang meliputi relevan dengan pengajaran dan berorientasi pada kualitas. (Mulyasa, E. 2006. Menjadi Guru Profesional (Menciptakan Pembelajaran Kreatif dan Menyenangkan). Bandung: Remaja Rosdakarya)

Profesi guru dalam undang-undang No.14 tahun 2005 tentang guru dan dosen mengharuskan sebuah komponen pokok yang harus dimiliki seorang guru profesional, kompetensi tersebut adalah; kompetensi profesional, kompetensi pedagogik, kompetensi sosial, dan kompetensi kepribadian.

1. Kompetensi Profesional guru

Kompetensi profesional guru berasal dari dua kata yaitu kompetensi dan profesional. Pengertian dasar kompetensi adalah kemampuan atau kecakapan. Dalam arti lain kompetensi profesional guru ialah kemampuan dan kewenangan guru dalam menjalankan profesi keguruannya, artinya guru yang piawai dalam melaksanakan profesinya dapat disebut sebagai guru yang kompeten dan profesional. Kompetensi profesional merupakan pekerjaan yang hanya dapat dilakukan oleh seorang yang mempunyai kualifikasi akademik, kompetensi dan sertifikat pendidik sesuai dengan persyaratan unutk pendidikan tertentu. 
2. Kompetensi pedagogik guru

Pedagogik adalah teori mendidik yang mempersoalkan apa dan bagaimana mendidik sebaik baiknya. (Suardi, 1979:113) sedangkan menurut pengertian Yunani pedagogik adalah ilmu menuntuk anak yang membicarakan masalah atau persoalan-persoalan dalam pendidikan dan kegiatan-kegiatan mendidik, tugas guru yang utama adalah mengajar dan mendidik murid dikelas maupun diluar kelas guru selaln-persoalan dalam pendidikan dan kegiatankegiatan mendidik, tugas guru yang utama adalah mengajar dan mendidik murid dikelas maupun diluar kelas guru selaln-persoalan dalam pendidikan dan kegiatan-kegiatan mendidik, rugas guru yang utama adalah mengajar dan mendidik murid dikelas maupun diluar kelas guru selalu berhadapan dengan murid yang memerlukan pengetahuan, keterampilan dan sikap utama untuk menghadapi hidupnya dimasa depan. Dilihat dari proses pembelajaran kompetensi pedagogik merupakan kemampuan guru dalam pengelolaan perkembangan pembelajaran peserta didik. Hal ini harus mampu diwujudkan oleh setiap guru untuk kehidupan bangsa.

3.Kompetensi sosial guru

Merupakan kemampuan guru untuk memahami dirinya sebagai bagian dari masyarakat dan mampu mengembangkan tugas sebagao, anggota masyarakat dan warga negara (satori dkk, 2008:215). Dengan memahami dan menerapkan nilai dan norma yang berlaku dimasyarakat karen guru merupakan bagian dari masyarakat, selain itu dalam hal memenuhi tanggung jawab sebagai mana yang diatur, dalam pembukaan undang-undang dasar negara Republik Indonesia pada alinea keempat. Berkomunikasi lisan dan tertulis, menggunakan teknologi informasi komunikasi secara fungsional, bergaul secara aktif dengan pesesrta didik, sesama pendidik, tenaga pendidikan, orang tua atau wali peserta didik, serta bergaul secara santun masyarakat disekitar.

4. Kompetensi kepribadian guru

Merupakan salah satu jenis kompetensi yang perlu dikuasai seorang guru selain 3 jenis kompetensi lainnya; sosial, pedagogik dan profesional. Dalam penjelasan peraturan pemerintah no19 tahun 2005 tentang standar nsaional pendidikan disebutkan bahwa kompetensi kepribadian guru yaitu kepribadian yang mantap, stabil, dewasa, Arif dan bijaksana, berwibawa, berakhlak mulia dan mengembangkan diri secara berkelanjutan sementara itu menurut pemendikas N0.16 tahun 2007 tentang kualifikasi dan kompetensi guru menjelaskan kompetensi kepribadian untuk guru kelas dan guru mata pelajaran pada semua jenjang, pendidikan dari dasar hingga menengah.

(Amirudin, Konsep, Pendidik:80-84)

\section{SIMPULAN}

Profesi diartikan sebagai suatu pekerjaan yang bersifat profesional, profesi guru memiliki tanggung jawab dalam meningkatkan pendidikan, guru digolongkan dalam sebuah profesisebab diharuskan memilki persyaratan-persyaratan khusus dibidang pendidikan oleh karena itu peran hak dan kewajiban guru adalah membimbing mengarahkan, mendidik peserta didik serta membekali ilmu pengetahuan. Maka diperlukan keprofesionalisme dalam menjalankan fungsi dan membimbing peserta didik, kompetensi guru yang profesinoal adalah orang yang memiliki kemampuan dan keahlian tugas dang fungsinya 
sebagai guru dengan maksimal.Seorang guru berkaitan dengan aktivitas profesinya diharuskan mengetahui dan dapat menerapkan beberapa prinsip mengajar agar ia dapat melaksanakan tugasnnya secara profesional. komponen pokok yang harus dimiliki seorang guru profesional, kompetensi tersebut adalah; kompetensi profesional, kompetensi pedagogik, kompetensi sosial, dan kompetensi kepribadian.

\section{REFERENSI}

Efendi, I., Prawitasari, M., \& Susanto, H. (2021). Implementasi Penilaian Pembelajaran Pada Kurikulum 2013 Mata Pelajaran Sejarah. Prabayaksa: Journal of History Education, 1(1), 21-25.

Susanto, H. (2020). Profesi Keguruan. Banjarmasin: FKIP Universitas Lambung Mangkurat.

Susanto, H., \& Akmal, H. (2018). Efektivitas Penggunaan Aplikasi Pembelajaran Berbasis Mobile Smartphone Sebagai Media Pengenalan Sejarah Lokal Masa Revolusi Fisik Di Kalimantan Selatan Pada Siswa Sekolah Menengah Atas. HISTORIA: Jurnal Program Studi Pendidikan Sejarah, 6(2), 197-206.

Susanto, H., Irmawati, I., Akmal, H., \& Abbas, E. W. (2021). Media Film Dokumenter Masuknya Islam Ke Nusantara dan Pengaruhnya Terhadap Keterampilan Berpikir Kritis Siswa. HISTORIA: Jurnal Program Studi Pendidikan Sejarah, 9(1).

Syaharuddin, S., \& Susanto, H. (2019). Sejarah Pendidikan Indonesia (Era Pra Kolonialisme Nusantara sampai Reformasi). Banjarmasin: FKIP Universitas Lambung Mangkurat. 